\title{
Yield Losses Due to Crown Rust in Winter Oats in Alabama
}

\author{
K. L. Bowen, Professor, and A. K. Hagan, Extension Specialist and Professor, Department of Entomology and Plant Pathology, Auburn \\ University, AL 36874; M. Pegues, Director, and J. Jones, Associate Director, Gulf Coast Research and Extension Center, Alabama \\ Agricultural Experiment Station, Fairhope 36532
}

Accepted for publication 15 April 2016. Published 4 May 2016.

\section{ABSTRACT}

Bowen, K. L., Hagan, A. K., Pegues, M., and Jones, J. 2016. Yield losses due to crown rust in winter oats in Alabama Plant Health Prog. 17:95-100.

Crown rust is a common disease on winter oats in Alabama. While considered the most destructive disease of oats, little has been done in recent years, with current cultivars, to demonstrate yield losses due to crown rust. Field studies were conducted to determine the effect of fungicides and application timing on crown rust severity and yield. All fungicides reduced crown rust and improved yield. Two fungicide applications were better than a single fungicide application for reducing crown rust. Relative to yield, a single fungicide application during flag leaf development (FS 8-9) was better than a single application during head extension (FS 10.3). When compared with the non-treated control, significant yield gains were obtained with Tilt and Headline in all four years and Stratego YLD in three of four years. Fungicide programs resulted in a broad range of crown rust severities; disease levels were highly related to decreases in yield in each of four years. In two study years, 'Coker 227 ' was more damaged by crown rust, with about $10 \%$ yield loss for each unit disease, than was 'Horizon 270,' with 2.5 to $4.5 \%$ loss. However, in 2013, virulence patterns of the crown rust pathogen shifted and disease on Horizon 270 was greater than that on Coker 227; relative yield losses were also much lower in 2013.

\section{INTRODUCTION}

Winter oats are grown as a winter cover crop as well as for grain on more than 40,000 acres annually in Alabama. In recent years, the value of oat production for grain in Alabama has exceeded \$4 million (USDA-NASS). Among the threats to oat production, crown rust, caused by Puccinia coronata f. sp. avenae P. Syd. \& Syd. (Fig. 1), has long been considered the most damaging fungal disease of domesticated oat, Avena sativa $\mathrm{L}$. (Simons 1985). While crown rust is best managed by host resistance, the average life span of a new resistant cultivar is often less than 5 years (Carson 2011). Cultivars are relatively shortlived because $P$. coronata undergoes sexual recombination on its alternate host, the common buckthorn (Rhamnus cathartica L.), in parts of the north-central United States.

Common buckthorn is not found in Alabama (USDA NRCS 2015); however, $P$. coronata successfully oversummers or is readily disseminated into southern states during spring months when moderate temperatures prevail along with extended dew periods. Urediniospores are capable of driving multiple infection cycles from February through May in Alabama, resulting in almost yearly severe crown rust epidemics.

Crown rust has been observed to kill winter oats when plants are attacked at early stages of growth (Simons 1985). More benignly, this disease can reduce the plants' ability to withstand winter injury (Simons 1985), which could decrease yield. In Canada, $P$. coronata was reported to cause $20 \%$ yield reduction on spring oats when severity reached $100 \%$ by maturity (Clark 1968). In Illinois, $20 \%$ crown rust severity at mid-milk (Feekes' stage (FS) 11.1) resulted in 19 and $28 \%$ yield reduction on the

Corresponding author: K. L. Bowen. Email: bowenk1@auburn.edu.

doi:10.1094/PHP-RS-16-0016

(C) 2016 The American Phytopathological Society spring oat cultivars Ogle and Noble, respectively (Bissonnette et al. 1994).

Given the potential for severe crown rust epidemics in southern states, the magnitude of potential losses, and the relatively short life span of resistant cultivars, it is important to understand fungicidal efficacy on oats. Preliminary reports have been published (Hagan and Pegues 2009; Hagan et al. 2010, 2015). In addition to evaluating the influence of application number and timing on fungicide efficacy, we sought to demonstrate yield losses due to crown rust on winter oats.

\section{FIELD EVALUATIONS}

This study was conducted at the Gulf Coast Research and Extension Center (GCREC) in Fairhope, AL, beginning in late autumn 2007. A single cultivar, Coker 227, was evaluated in the first two seasons of this study (harvested in May 2008 and 2009

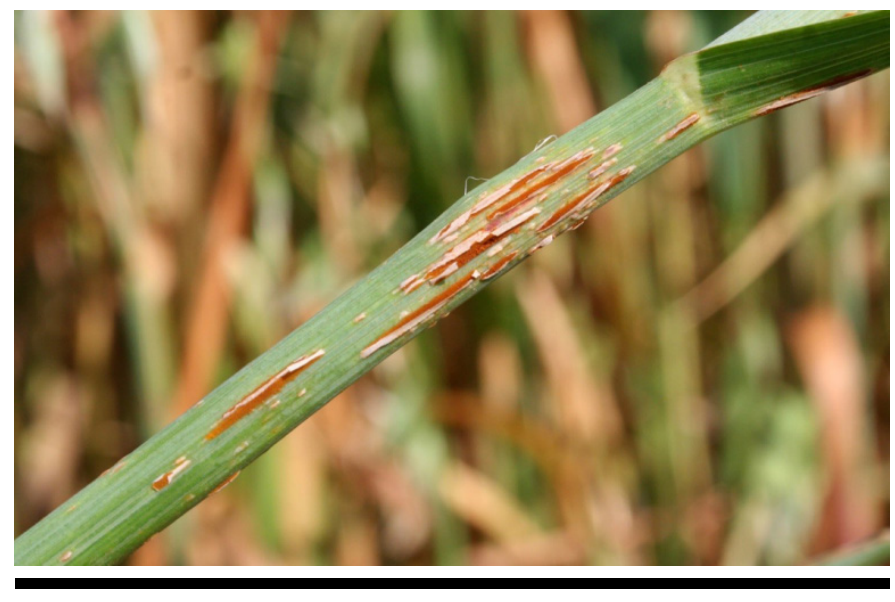

FIGURE 1

Crown rust caused by Puccinia coronata on winter oat in Alabama. 
and herein referred to by year of harvest), while a second cultivar, Horizon 270, was included for evaluation in 2012 and 2013. Both of these cultivars are considered to be resistant to crown rust (Anonymous 2015; Harrison et al. 2006). Details on production practices are provided in Table 1 . In general, winter oats were planted in late November or early December. Prior to planting, a starter fertilizer was broadcast and incorporated; additional nitrogen was topdressed in February.

The experimental design was a randomized complete block with four replications of each treatment in all study years. For the 2012 and 2013 evaluations with two cultivars, fungicide treatments were randomized as sub-plots within main plots of each cultivar. In each year, fungicide-treated plots were $8 \mathrm{ft}$ wide by $25 \mathrm{ft}$ long. Fungicides were applied in the equivalent of 15 gal/acre volume using a $\mathrm{CO}_{2}$ backpack sprayer. In 2008, there were 12 treatments: a non-treated control plus different programs involving application timings and rates with five fungicides. Three application timing programs were done with each of two fungicides, Tilt 3.6EC (propiconazole, $4 \mathrm{fl}$ oz/acre; Syngenta Crop Protection, Greensboro, NC) and Stratego 2.08EC (propiconazole + trifloxystrobin, $7 \mathrm{fl}$ oz/acre; Bayer CropScience, Research Triangle Park, NC). The three application timing programs were: a single application at FS 8-9 (flag leaf emerging to fully emerged); a single application at FS 10.3 (head extension); and two applications at both FS 8-9 and FS 10.3. Two additional fungicides were applied at FS 8-9 at each of two rates: Headline 2.09SC at 6 and 9 fl. oz/acre (pyraclostrobin; BASF Corp., Research Triangle Park, NC) and Quadris 2.08SC at, 3.1 and $6.2 \mathrm{fl}$ oz/acre (azoxystrobin; Syngenta). A treatment with Quilt 1.67EC (propiconazole + azoxystrobin, $10.5 \mathrm{fl}$ oz/acre; Syngenta) at FS 8-9 was also included in 2008. In 2009, 2012, and 2013, fourteen treatments included a non-treated control plus three application timing programs with each of four fungicides (Tilt and Stratego at same rates as in 2008, Quadris at $4 \mathrm{fl}$ oz/acre, and Headline at $6 \mathrm{fl} \mathrm{oz/acre).} \mathrm{Application} \mathrm{times} \mathrm{were} \mathrm{the} \mathrm{same} \mathrm{as}$ in 2008: a single application at FS 8-9; a single application at FS 10.3; and two applications at FS 8-9 then at FS 10.3. Headline at $9 \mathrm{fl} \mathrm{oz/acre} \mathrm{applied} \mathrm{at} \mathrm{FS} \mathrm{8-9} \mathrm{was} \mathrm{also} \mathrm{included} \mathrm{as} \mathrm{a} \mathrm{treatment.}$

Crown rust was visually estimated on the flag leaf of 10 randomly selected tillers on a 0 to 10 scale where $0=$ no disease, $1=1$ to $10 \%$ severity, $2=11$ to $20 \%$ severity, and so on to $10=$ leaves dead due to disease. Means of the rust scores of 10 tillers were recorded for each plot. Rust ratings were planned for the soft dough stage (FS 11.2) in mid- to late-April (Table 1). Plots were mechanically harvested at maturity; yields are reported at $10 \%$ moisture.

Data were checked for normality and outliers in each study year. Outliers were defined as greater (or less) than the mean plus (or minus) three standard deviations of each measured variable.
The few outliers that were found appeared to be data entry errors and were removed from the dataset. Analyses were done on rank transforms of non-normal data. Data are back-transformed for presentation. Significance of treatment effects were determined with mixed model analysis (Proc GLIMMIX in SAS 9.2 and 9.3; SAS Institute Inc., Cary, NC). Factorial analysis was also done on data from the fungicide $\times$ application timing treatments in each year. Means were differentiated using Fisher's protected least significant difference (FLSD) test $(P \leq 0.05)$. Crown rust ratings (average per plot) were used as independent variables in regression analyses with yield as the dependent variable for developing yield loss models for each year. Parameters from each model were tested for similarity to those in other models using an $F$ test $(P \leq 0.05)$ (Proc REG in SAS 9.3).

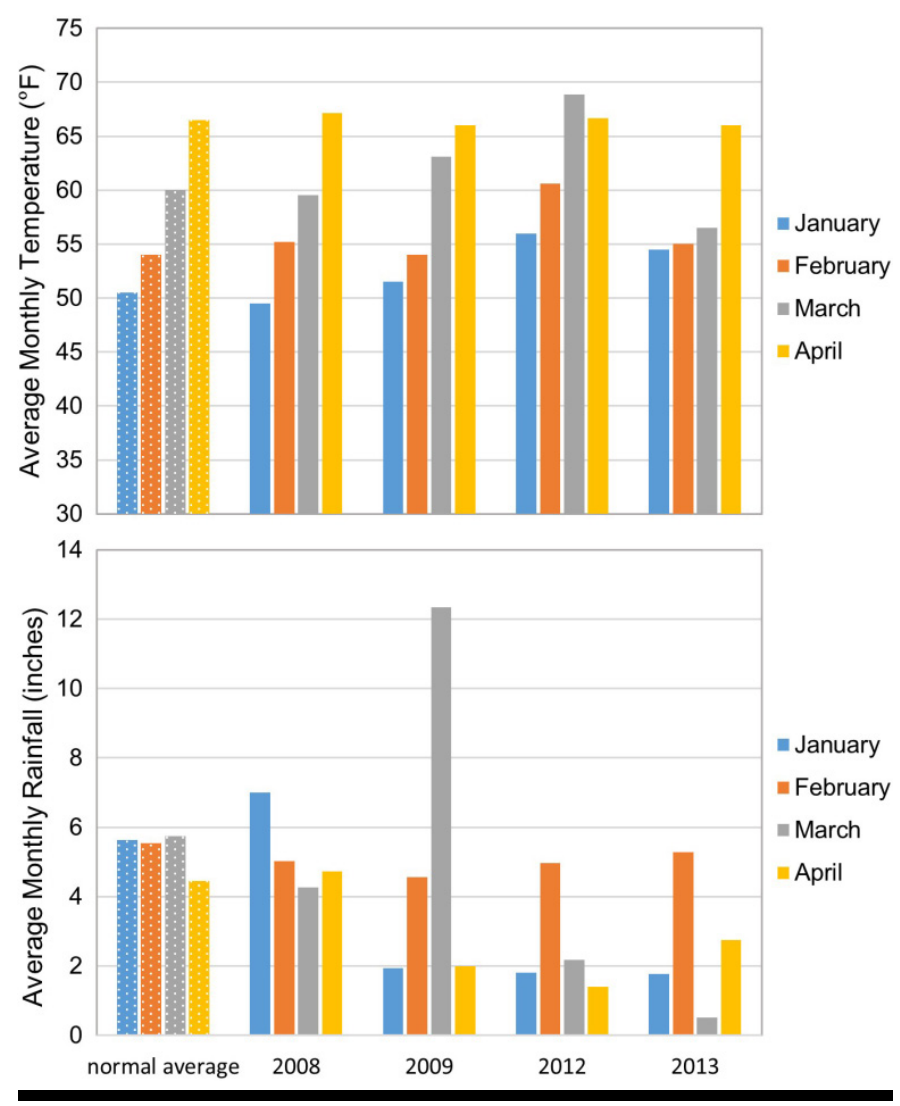

FIGURE 2

Average monthly temperatures and rainfall for January, February, March, and April of study years. Data were collected on location through the Alabama Mesonet.

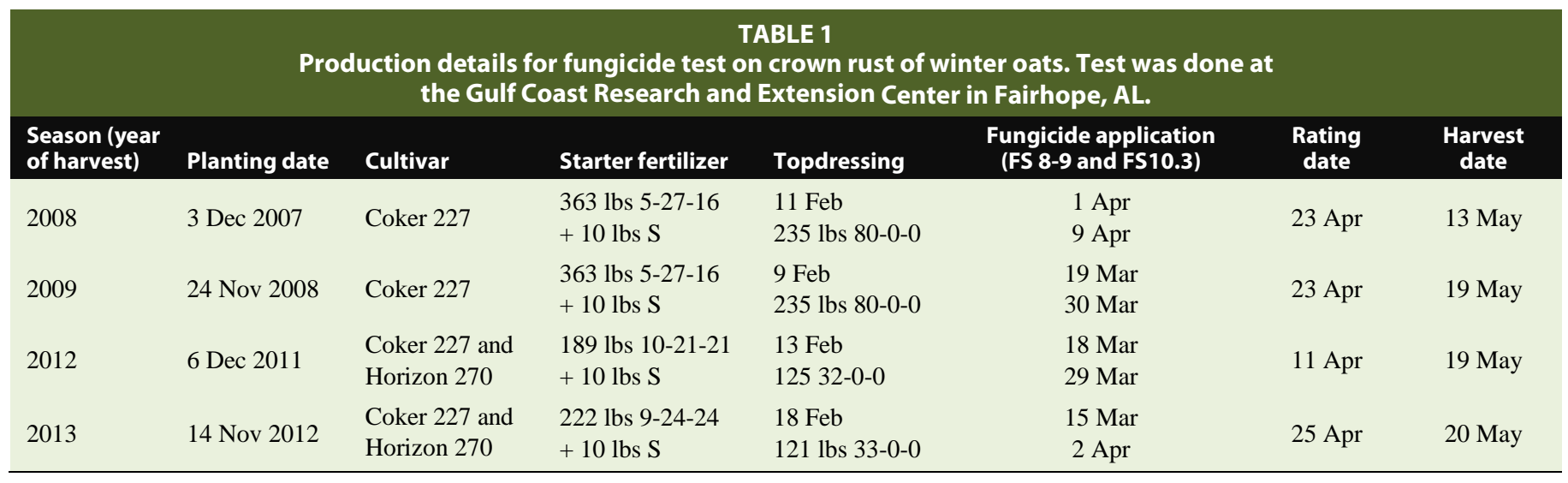




\section{WEATHER}

Daily temperature (minimum and maximum) and rainfall amounts were recorded by and collected from the AL Mesonet station at GCREC. Plots were within $4500 \mathrm{ft}$ of this weather station. From these data, average monthly maximum and minimum temperatures were calculated. January through April monthly temperatures were generally within $3^{\circ} \mathrm{F}$ of normal (30year) averages (Fig. 2), except in 2012 when January through March were several degrees warmer than average and in 2013
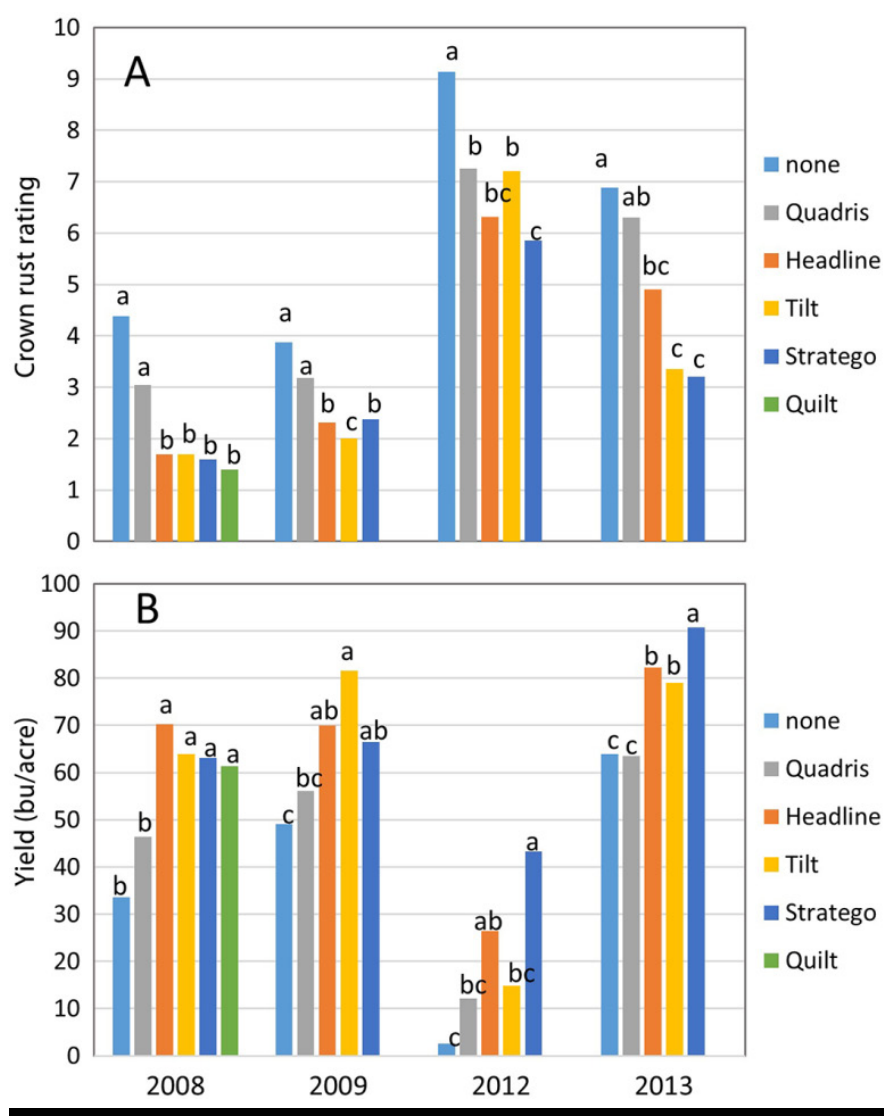

FIGURE 3

Crown rust scores (A) and yields (B) of non-treated and FS 8-9 fungicide treated plots of Coker 227 in each study year. Data are means of four replications. Crown rust scores reflect $10 \%$ increments of damage on flag leaves, such that $0=0$ to $10 \%$ damage, $1=10$ to $20 \%$ damage, etc. Letters associated with bars, when different within any one year, indicate significant differences according to Fisher's protected least significant difference test at $P<0.05$. when January was warmer than normal but March was cooler. Since crown rust develops most rapidly at 70 to $77^{\circ} \mathrm{F}$ (Carson 2008), temperature averages greater than $65^{\circ} \mathrm{F}$ in March 2012 and in April of all four years were conducive for crown rust. Rainfall was relatively limited in both 2012 and 2013 compared to historical averages (Fig. 2).

\section{EFFECTS OF FUNGICIDES}

In 2008, two application rates of Quadris (3.1 and $6.2 \mathrm{fl}$ oz/acre), applied at FS 8-9, were included in the study. Disease levels and yield did not differ either between rates of Quadris
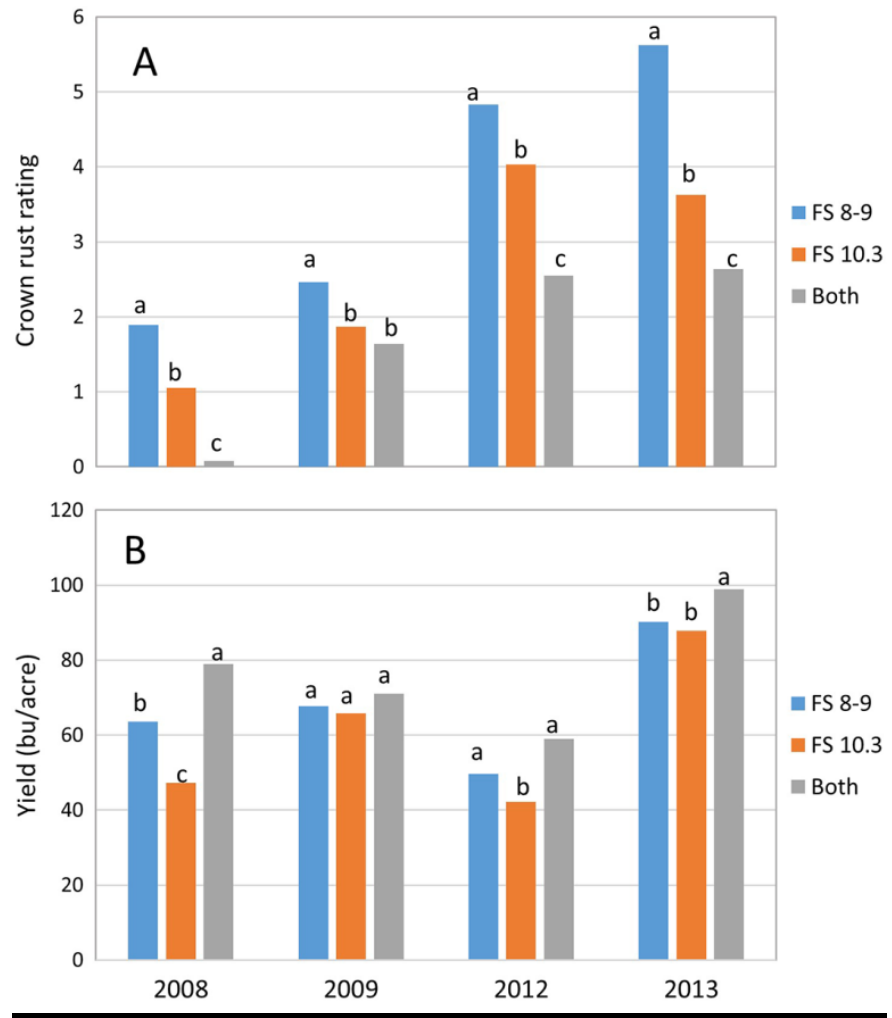

\section{FIGURE 4}

Crown rust scores (A) and yields (B) from factor analysis of application timing data from each study year. Crown rust scores reflect $10 \%$ increments of damage on flag leaves, such that $0=0$ damage, $1=>0$ to $10 \%$ damage, $2=10$ to $20 \%$ damage, etc. Letters associated with bars, when different within any one year, indicate significant differences according to Fisher's protected least significant difference test at $P<0.05$.

\begin{tabular}{|c|c|c|c|c|c|c|}
\hline \multicolumn{7}{|c|}{ 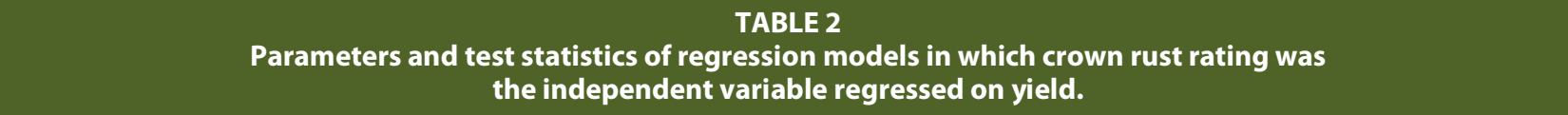 } \\
\hline Year & Cultivar & Interceptv & Coefficientw & Relative loss $(\%)^{x}$ & $R$-squared & $P$-value \\
\hline $2008^{y}$ & Coker 227 & $73.74 \mathrm{~d}^{\mathrm{z}}$ & $-8.78 c^{z}$ & $-11.9 \mathrm{a}^{\mathrm{z}}$ & 45.8 & $<0.0001$ \\
\hline 2009 & Coker227 & $90.22 \mathrm{c}$ & $-10.70 \mathrm{~d}$ & $-11.9 \mathrm{a}$ & 69.8 & $<0.0001$ \\
\hline 2012 & Coker 227 & $54.04 \mathrm{e}$ & $-5.25 \mathrm{bc}$ & $-9.7 \mathrm{a}$ & 38.7 & $<0.0001$ \\
\hline & Horizon 270 & $116.80 \mathrm{a}$ & $-2.92 \mathrm{a}$ & $-2.5 \mathrm{c}$ & 42.9 & $<0.0001$ \\
\hline
\end{tabular}

\footnotetext{
${ }^{\mathrm{v}}$ Model intercept reflects yield potential (bu/acre) for each cultivar in each year.

"Model coefficient is the "slope" of the line described by the model and reflects change in yield per unit disease.

${ }^{\mathrm{x}}$ Relative loss $=($ coefficient/intercept $) \times 100$, which reflects the percentage loss per unit disease relative to model intercept.

$\mathrm{y}$ Winter oats are planted in the fall and harvested in spring; year is year of harvest for identifying each study.

${ }^{\mathrm{z}}$ Values within a column followed by the same letter(s) are not significantly different according to $F$-test test at $P<0.05$.
} 
application or between Quadris applications and the non-treated control (data not shown). In subsequent study years, Quadris was applied at $4 \mathrm{fl}$ oz/acre, which is less than label rates (6 to $12 \mathrm{fl}$ oz/acre) so that varying disease levels could be achieved for determining yield losses. Significantly lower crown rust with Quadris application at FS 8-9 compared to the non-treated control (Fig. 3A) was noted only in 2012. Despite this efficacy with $4 \mathrm{fl}$ oz/acre, growers should never apply fungicides at rates lower than stated on a label due to the possibility that a sub-lethal rate could lead to fungicide resistance in a target pathogen (Deising et al. 2008) and increase the risk of fungicide failure.

Two application rates of Headline (6 and $9 \mathrm{fl} \mathrm{oz/acre),} \mathrm{applied}$ at FS 8-9, were compared in all four study years. Rust levels did not differ significantly due to application rate of Headline (data not shown). Although not significantly different due to application rate, yield was 4 to $16 \%$ greater with the higher than with the lower rate of Headline (data not shown).

Using data from Coker 227, disease levels and yields from FS 8-9-treated and the non-treated control plots were compared to each other to evaluate product efficacy. Quilt, evaluated only in 2008, and in all study years, Stratego, Tilt, and Headline, significantly reduced crown rust compared to non-treated plots (Fig. 3A). In all four years of this study, Tilt and Headline significantly improved yield compared to non-treated plots (Fig. 3B). Applications of Stratego significantly improved yield compared to control plots in 3 of 4 years (Fig. 3B).
In the factorial analysis of four fungicides with 3 application timings, there were no significant 2-way (or 3-way with cultivar in 2012 and 2013) interactions. Differences among products were similar to results of analysis that included the non-treated plots, noted above; i.e., rust levels and yields were similar with Tilt, Stratego, or Headline application. Relative to application timings, factorial analysis showed that with the single application at head emergence (FS 10.3), crown rust was lower than with fungicide application to the flag leaf (FS 8-9), and in 3 of 4 years, two fungicide applications resulted in lower disease than either single application (Fig. 4A). Despite reduced crown rust ratings, yield was consistently lower with the single fungicide application at FS 10.3 (during heading) compared to programs with the single earlier application at FS 8-9 (flag leaf emergence) (Fig. 4B). The single fungicide application at FS 10.3 would have left the flag leaf unprotected from rust for some period of time ( 8 to 18 days, depending on year) during boot stage and head emergence which could explain the lower yield.

\section{CULTIVAR DIFFERENCES}

In 2012, crown rust on Coker 227 was significantly greater than on Horizon 270 (ratings of 9.1 and 4.2, respectively on nontreated plots), while in 2013, the reverse was true (6.9 and 9.5, respectively). Coker 227 was originally developed with a rust resistance gene, Pc-60, from A. sterilis (Carson 2011) and is described by some as "crown rust resistant" (Anonymous 2015).
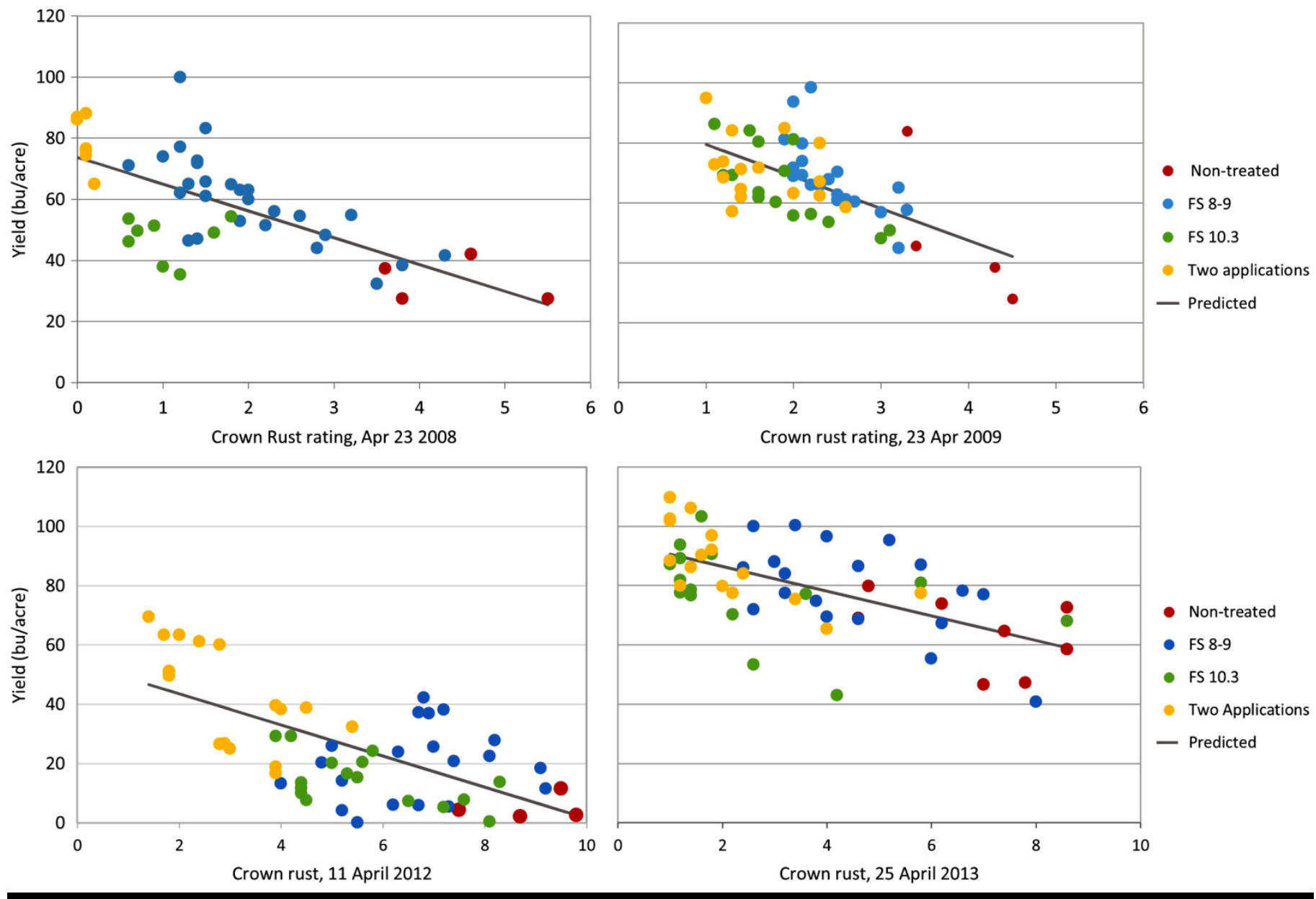

FIGURE 5

Yield (bu/acre) and crown rust scores on Coker 227 in four study years. Disease levels were attained with varying fungicide programs; different products were applied once at flag leaf emergence (FS 8-9), head extension (FS 10.3), or applied at both stages. Rust ratings were generally based on $10 \%$ increments of damage to flag leaves. Lines represent yield loss models (see Table 2). 
However, as early as 1991 a majority of $P$. coronata isolates collected in Texas were found to be virulent on $P c-60$ (Leonard et al. 2004), which would have resulted in an apparent decrease in the resistance of Coker 227. Prior to 2013, Horizon 270 was also considered a crown rust resistant cultivar, especially when compared to Coker 227 (Hagan 2008). However, in the spring of 2013, a shift in $P$. coronata races apparently occurred, which led to a severe crown rust outbreak on Horizon 270 (S. A. Harrison, personal communication), although the specific race changes are unknown at this time (S. F. Kianian, personal communication). Horizon 270 was initially included in Uniform Winter Oat Nurseries in 2005 (Harrison et al. 2006), indicating that this cultivar has had an estimated lifespan of about 8 years.

\section{YIELD LOSSES}

Fungicide programs provided a range of crown rust severities in each year. In non-treated plots, disease scores averaged about 4 in 2008 and 2009, and 7 to 9 (up to 90\% severity) in 2012 and 2013 (Fig. 3A). Two applications of fungicides reduced crown rust by 70 to $80 \%$, or to scores averaging <3 (less than $30 \%$ severity) (Fig. 4A).

Regression models indicated a highly significant $(P<0.0005)$ effect of disease on yield in each year (Table 2). Intercepts of the models, which indicate yield potential in each year for each cultivar, ranged from 54 bu/acre for Coker 227 in 2012 to 116 bu/acre for Horizon 270 in 2013. These intercepts differed significantly between models, so data were not combined over years or cultivars for a composite model. Coefficients on the rust variable in these models (Table 2), indicating the amount of loss per unit increase in disease, varied from -2.9 bu/acre on Horizon 270 in 2013 to $-10.7 \mathrm{bu} /$ acre on Coker 227 in 2009. Relative loss $[=($ coefficient $/$ intercept $) \times 100]$ is the percentage decrease in yield potential for each unit increase in disease and allows comparisons between years despite differences in yield potential. In three of four study years $(2008,2009$, and 2012), one unit increase in disease caused 10 to $12 \%$ relative loss in yield of Coker 227; relative losses were significantly lower in 2013, with only $4 \%$ loss per unit disease.

Average state-wide yields for oats in Alabama have ranged from 45 to $65 \mathrm{bu} / \mathrm{acre}$ in recent years (USDA-NASS), which is generally lower than the yield potential indicated by the regression models. It may be that production practices by growers are not optimized as they would be for a research study at GCREC. For example, given limited returns on oats, growers may not apply fungicides and this would decrease yield even with low to moderate levels of disease.

In both years in which the two cultivars were compared, Horizon 270 consistently had greater yield potential (= intercepts) and lower relative loss than Coker 227 (Table 2, Figs. 5 and 6). This comparison suggests that Horizon 270 has greater tolerance to crown rust than does Coker 227, i.e., despite greater disease, Horizon 270 yields better than Coker 227.

In 2013, higher model intercepts and lower relative losses were noted on both varieties than in preceding years (Table 2, Figs. 5 and 6). It could be that cool temperatures, which prevailed into March of 2013, with lower than normal rainfall in January, March, and April, delayed crown rust onset and suppressed rust development which could have contributed to higher yields. When temperatures warmed, crown rust developed rapidly in April resulting in severe disease by the 25 April rating date in 2013.

\section{CONCLUSIONS}

This study has shown that several fungicides are equally efficacious for managing crown rust on oats. Fungicides should be used at label rates and applied so that the flag leaf is protected

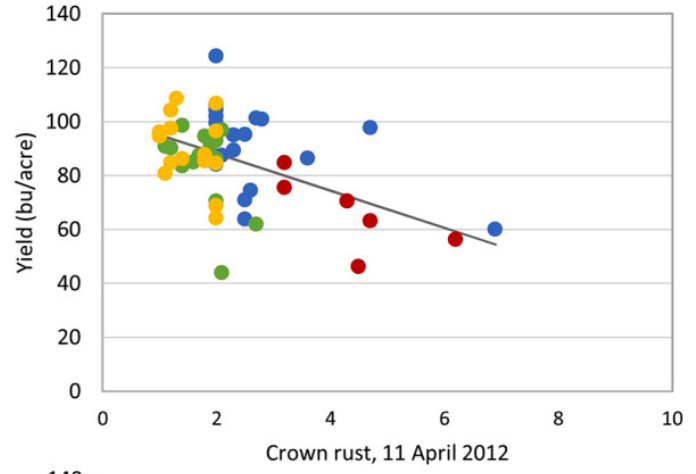

- Non-treated
- FS 8-9
- FS 10.3
Two applications

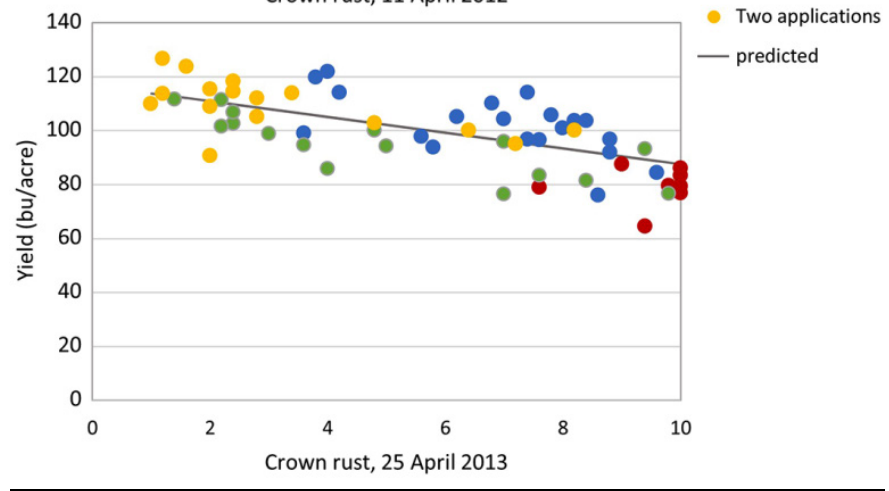

FIGURE 6

Yield (bu/acre) and crown rust scores on Horizon 270 in two study years. Disease levels were attained with varying fungicide programs; different products were applied once at flag leaf emergence (FS 8-9), head extension (FS 10.3), or applied at both stages. Rust ratings were generally based on $10 \%$ increments of damage to flag leaves. Lines represent yield loss models (see Table 2).

soon after its emergence. Results also show that losses due to crown rust on winter oats can range from about 3 to 10.4 bu/acre per unit disease, depending on year and cultivar. The disease scores used in this study were based on $10 \%$ increments of damage due to crown rust, suggesting that $1 \%$ increase in such damage could mean yield losses of 0.3 to $1 \mathrm{bu} /$ acre (20 to 70 $\mathrm{kg} / \mathrm{ha}$ ). These losses are comparable to the 19 to $28 \mathrm{~kg} / \mathrm{ha}$ loss in spring oats noted by Bissonnette et al. (1994). A single fungicide application at FS 8-9 in this study reduced crown rust by an average of 2 disease units, thus improving yield by 5.9 to 20.8 bu/acre. With oat prices averaging $\$ 3.70 /$ bu over recent years (USDA-NASS), this could be an income gain of $\$ 21$ to $\$ 77$ per acre, and in some years, could justify a fungicide application.

\section{ACKNOWLEDGMENTS}

Funding for this research was through the Alabama Agricultural Experiment Station.

\section{LITERATURE CITED}

Anonymous. 2015. Certified Oat Buyers Guide. Georgia Crop Improvement Assoc., Athens, GA.

Bissonnette, S. M., D’Arcy, C. J., and Pedersen, W. L. 1994. Yield loss in two spring oat cultivars due to Puccinia coronata f.sp. avenae in the presence or absence of barley yellow dwarf virus. Phytopathology 84:363-371.

Carson, M. L. 2008. Virulence frequencies in oat crown rust in the United States from 2001 through 2005. Plant Dis. 92:379-384.

Carson, M. L. 2011. Virulence in oat crown rust (Puccinia coronata f. sp. avenae) in the United States from 2006 through 2009. Plant Dis. 95:15281534.

Deising, H. B., Reimann, S., and Pascholati, S. F. 2008. Mechanisms and significance of fungicide resistance. Braz. J. Microbiol. 39:286-295. 
Hagan, A. K. 2008. Oat disease control for 2008-2009 production season. Plant Pathol. Series. Ala. Coop. Ext. Publ. PP-658. Auburn, AL.

Hagan, A., and Pegues, M. 2009. Fungicides evaluated for the control of crown rust on oats, 2008. PDMR 4:CF017. doi:10.1094/PDMR04.

Hagan, A., Pegues, M., and Jones, J. 2010. Comparison of fungicides for control of crown rust on oats, 2009. PDMR 4:CF018. doi:10.1094/PDMR04

Hagan, A., Pegues, M., and Jones, J. 2015. Fungicides compared for the control of crown rust on two oat varieties in Southwest Alabama, 2013. PDMR 9:CF002. doi:10.1094/PDMR09.

Harrison, S. A., Barnett, R. D., Arceneaux, K., Edge, B., Johnson, J., Murphy, P., and Mascagni, H. J. 2006. Horizon 270 Oat: A new winter oat cultivar.
Variety release note; Breeder's description. Southeastern University GRAINS (SunGrains), LSU AgCenter, Baton Rouge, LA.

Leonard, K. J., Anikster, Y., and Manisterski, J. 2004. Patterns of virulence in natural populations of Puccinia coronata on wild oat in Israel and in agricultural populations on cultivated oat in the United States. Phytopathology 94:505-514.

Simons, M. D. 1985. Crown rust. Pages 131-172 in: The Cereal Rusts: Vol II. Disease, Distribution, Epidemiology, and Control. A. P. Roelfs and W. R. Bushnell, eds. Academic Press, Orlando, FL.

USDA, NRCS. 2015. The PLANTS Database (http://plants.usda.gov). National Plant Data Team, Greensboro, NC. 